\title{
Enantioselective Cooperative Catalysis within Frustrated Lewis Pair Complexes
}

\author{
Masayuki Wasa* and Ahmet Yesilcimen \\ * Department of Chemistry, Merkert Chemistry Center, Boston College \\ 2609 Beacon Street, Chestnut Hill, MA 02467, United States
}

(Received August 24, 2021; E-mail: wasa@bc.edu)

\begin{abstract}
Cooperative actions of two or more Lewis acid and/or Lewis base catalysts can be exploited to promote enantioselective transformations that are not readily achieved by a single catalyst system. Nonetheless, undesirable acid-base complexation which occurs in a reaction mixture containing the catalysts, substrates, and products often results in poor reaction efficiency and a contrived substrate scope. In this article, we highlight our development of multi-catalyst systems that facilitate enantioselective transformations of otherwise unreactive $\mathrm{C}-\mathrm{H}$ bonds contained in various carbonyl compounds and $\mathrm{N}$-alkylamines while overcoming the formation of inert Lewis adducts. Such methods were achieved through the identification of catalyst/substrate combinations that form frustrated Lewis pairs (FLPs), namely, highly active acids and bases whose mutual quenching is precluded due to steric and electronic factors.
\end{abstract}

\section{Introduction}

Enantioselective synthesis of desirable organic molecules can often be facilitated by the use of various combinations of Lewis acid and/or Lewis base catalysts that are designed to function cooperatively (i.e., cooperative catalysts; e.g., C1-C5, Figure 1a). ${ }^{1-8}$ A key advantage of a multi-catalytic process is that it facilitates an otherwise-difficult-to-perform union of non-isolable intermediates under neutral $\mathrm{pH}$ and redox-neutral conditions. ${ }^{1-8}$ For instance, various carbonyl compounds can be converted into enolate equivalents by deprotonation of
Lewis acid-activated carbonyl moieties by an appropriate Brønsted base (e.g., $\mathbf{1} \rightarrow \mathbf{I}$, Figure 1c). ${ }^{1-9}$ Ensuing reaction of the in situ generated enolate and a Lewis acid- (or hydrogen bond donor- $)^{4}$ activated electrophile affords a variety of enantioenriched products (e.g., $\quad \mathbf{I} \rightarrow \mathbf{2}){ }^{5}$ Despite the notable advances, significant shortcomings that limit the practical applications of cooperative catalysis remain unaddressed. A key problem in the state-of-the art involving Lewis acid and Lewis base catalysts is the self-quenching that may occur within a reaction solution that contains the catalysts, substrates and products. ${ }^{1-8}$ Such process can either slow down or termi-

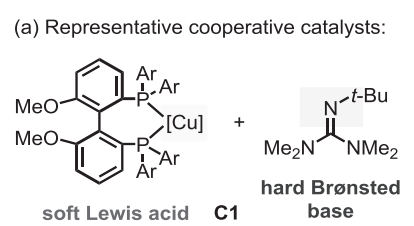

(b) Frustrated Lewis pairs:

$$
\left(\mathrm{C}_{6} \mathrm{~F}_{5}\right)_{3} \stackrel{\ominus}{\mathrm{B}} \stackrel{\oplus}{\mathrm{P}}(t-\mathrm{Bu})_{3}
$$

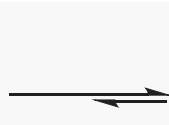

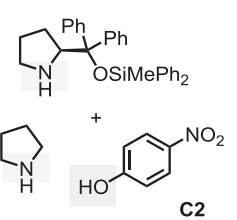
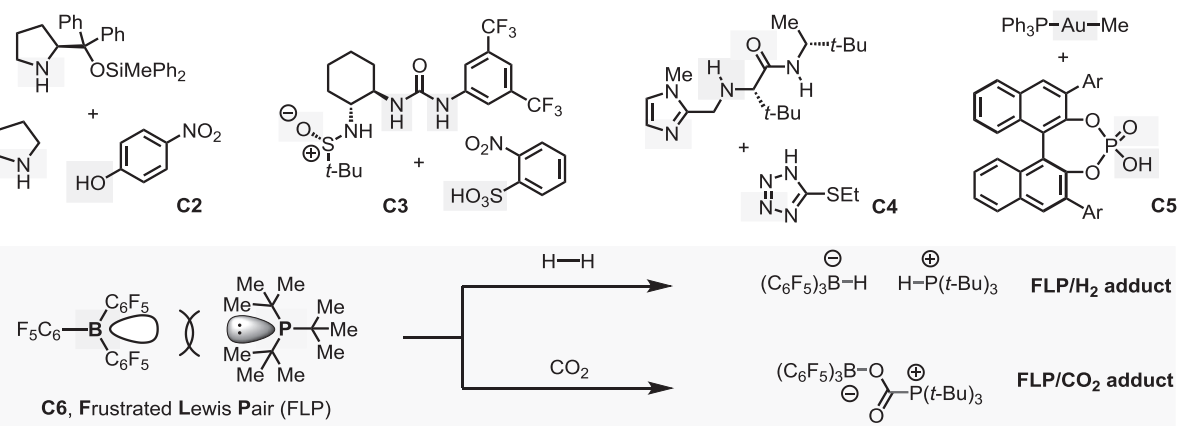

C6, Frustrated Lewis Pair (FLP)

(c) Enantioselective $\alpha$-functionalization of carbonyl compounds by cooperative catalysis (our work):

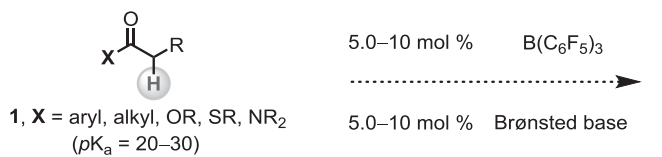
$\left(p K_{\mathrm{a}}=20-30\right)$

(d) Enantioselective $\alpha$ - and $\beta$-amino $\mathrm{C}-\mathrm{H}$ functionalization (our work):

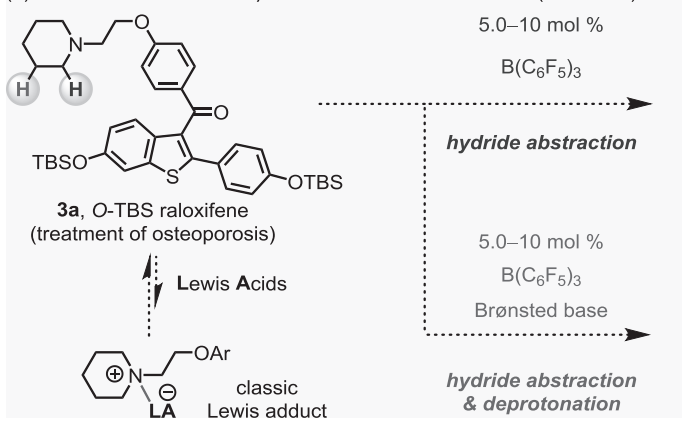

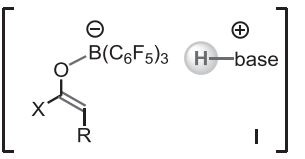
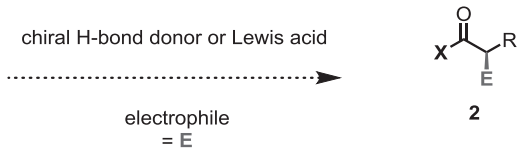

cooperative Lewis acid/Lewis acid catalysts:

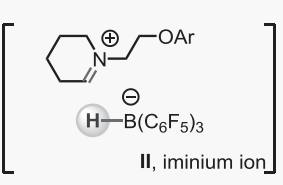

$5.0-10 \mathrm{~mol} \%$

chiral Lewis acid

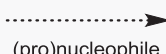

(pro)nucleophile
= Nuc

$=$ Nuc

cooperative Lewis acid/Brønsted base catalysts:

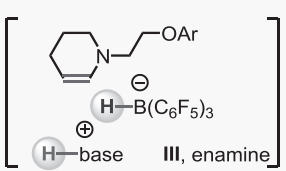

$5.0-10 \mathrm{~mol} \%$

chiral Lewis acid

electrophile

$=\mathrm{E}$

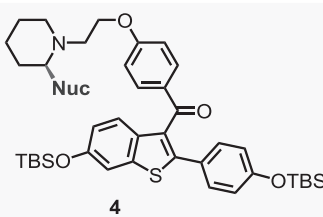

4

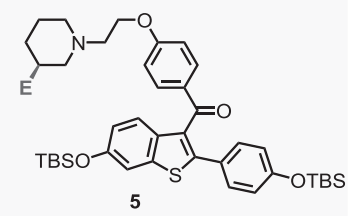

Figure 1. Structure and reactivity of cooperative catalysts. 
nate the target reaction. One strategy for circumventing acidbase complexation is to avoid catalyst combinations that have a strong affinity for each other (i.e., hard-hard or soft-soft pairing; e.g., C1), but then one is confined to catalysts that are only mildly Lewis acidic and/or Lewis basic. ${ }^{1-8}$ Consequently, the range of pronucleophiles that can be deprotonated by such weakly acidic and basic catalysts are often confined to those that contain a sufficiently acidic proton (e.g., 1,3-dicarbonyls, nitroalkanes, aldehydes, or ketones; $\left.\mathrm{p} K_{\mathrm{a}}=8-20\right) .{ }^{1-5}$ Moreover, because of the use of weaker Lewis acids, electrophiles that undergo efficient reactions with the in situ generated nucleophiles are limited to those that are highly pre-activated (e.g., nitroalkenes, $N$-tosyl imines, diethyl azodicarboxylate). ${ }^{1-5}$ On the other hand, the issue with utilizing stronger acids and/or bases, which are capable of activating less pre-activated substrates (e.g., carboxylic esters and amides; $\mathrm{p} K_{\mathrm{a}}=25-30$ ), is that they can form tightly bound acid-base adducts and therefore engender catalyst deactivation. ${ }^{10}$

The application of frustrated Lewis pairs (FLPs), consisting of hindered and electronically disparate Lewis acids and Lewis bases, has emerged as an attractive strategy for overcoming mutual quenching (Figure 1b). ${ }^{9,11-15}$ Since the seminal reports by Stephan and Erker on B/P-based FLP-mediated splitting of $\mathrm{H}_{2}$ to give $\mathrm{FLP} / \mathrm{H}_{2}$ (Figure 1b), ${ }^{11 \mathrm{a}, \mathrm{b}}$ an array of acid/base pairs have been exploited for the stoichiometric activation of $\mathrm{CO}_{2},{ }^{12 \mathrm{~b}-\mathrm{c}, \mathrm{f}-\mathrm{h}, \mathrm{l}} \mathrm{CO},{ }^{12 \mathrm{i}} \mathrm{N}_{2} \mathrm{O},{ }^{12 \mathrm{e}}$ alkene, ${ }^{12 \mathrm{n}}$ alkyne, ${ }^{12 \mathrm{~d}, \mathrm{l}}$ and others. Nonetheless, the development of catalytic transformations involving FLPs has been largely limited to the hydrogenation of unsaturated molecules. ${ }^{11,12}$

Additionally, FLPs that are comprised of a boron-based Lewis acid and a Lewis basic amine substrate bearing easily accessible $\alpha$-hydrogens have been shown to engage in Lewis acid-mediated hydride abstraction; such processes produce an iminium cation and a borohydride anion (e.g., $\mathbf{3 a} \rightarrow \mathbf{I I}$, Figure 1d). ${ }^{13-16}$ It is also known that the amine-derived iminium can be deprotonated by an appropriate Brønsted base to afford an enamine (e.g., 3a $\rightarrow$ III, Figure 1d). ${ }^{15}$ However, at the time we began our investigations in 2016, engagement of iminium ions and enamines formed by organoborane-catalyzed hydride abstraction from amines in the context of a catalytic reaction was limited to dehydrogenation of $\mathrm{N}$-containing heterocycles. ${ }^{16}$ Moreover, these strategies were yet to be successfully applied to catalytic and enantioselective $\mathrm{C}-\mathrm{C}$ bond forming processes.

In this article, we will highlight our development of multicatalytic processes wherein the undesired acid-base complexation among the catalysts, substrates and products is suppressed because they are electronically and sterically "frustrated". The discussion is organized in the framework of two types of processes. In the first part (section 2), we describe that the FLP catalysts facilitate enantioselective transformations of $\alpha-\mathrm{C}-\mathrm{H}$ bonds contained in various mono-carbonyl compounds (Figure 1c). ${ }^{17}$ In the second part (section 3), enantioselective transformations of $\alpha-$ and $\beta-\mathrm{C}-\mathrm{H}$ bonds within $N-$ alkylamines and applications of such methods to late-stage derivatizations of bioactive amines are outlined (Figure 1d). ${ }^{18}$
2. Frustrated Lewis Acid/Brønsted Base Catalysts for Enantioselective $\alpha$-Functionalization of Carbonyl Compounds

\subsection{FLP-catalyzed Enantioselective $\alpha$-Amination of Carbonyl Compounds}

We have developed a method for $\alpha$-amination of various mono-carbonyl compounds catalyzed by a sterically and electronically "frustrated" Lewis acid/Brønsted base complex (Figure 2a). ${ }^{17 a}$ It was found that a catalyst combination of $\mathrm{B}$ $\left(\mathrm{C}_{6} \mathrm{~F}_{5}\right)_{3}$ and 1,2,2,6,6-pentamethylpiperidine (PMP) promotes the efficient deprotonation of ketone $\mathbf{1} \mathbf{a}$, ester $\mathbf{1 b}$, and thioester $1 \mathrm{c}\left(\mathrm{p} K_{\mathrm{a}}=\mathrm{ca} .20-25\right)$ and the subsequent union of the resulting boron enolates with dimethyl azodicarboxylate (DMAD) to afford $\mathbf{2 a - 2 c}$ in $88-98 \%$ yield. For $\alpha$-amination of amide 1d possessing a less acidic $\alpha-\mathrm{C}-\mathrm{H}$ bond ( $\mathrm{p} K_{\mathrm{a}}=\mathrm{ca}$. 30), Barton's base was used to produce $2 \mathbf{d}$ in $65 \%$ yield. We then developed an enantioselective version of the catalytic process with $\alpha^{-}$ tetralone (1e, Figure 2b) serving as the model substrate.

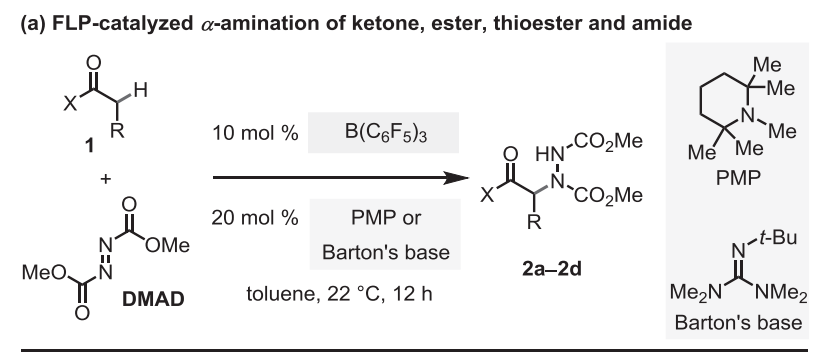

$$
\text { 2a, } 98 \% \text { yield }
$$
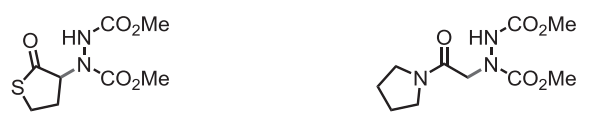

2c, $97 \%$ yield

2d, $65 \%$ yield

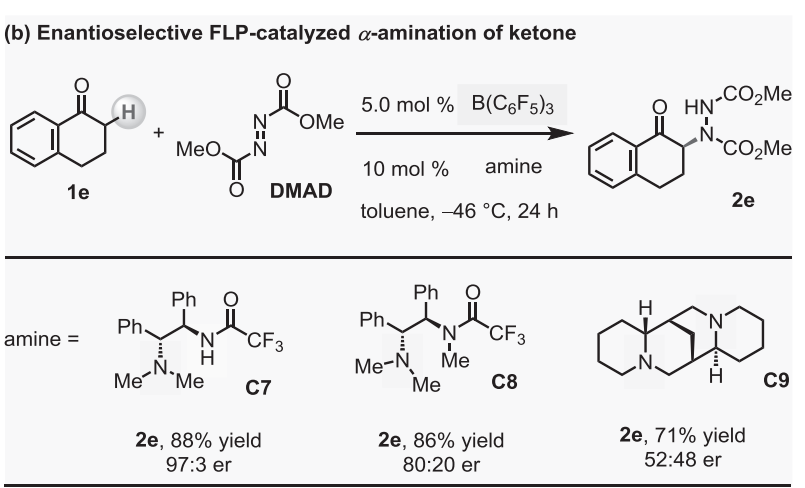

(c) Dual vs single $\mathrm{H}$-bonding interactions

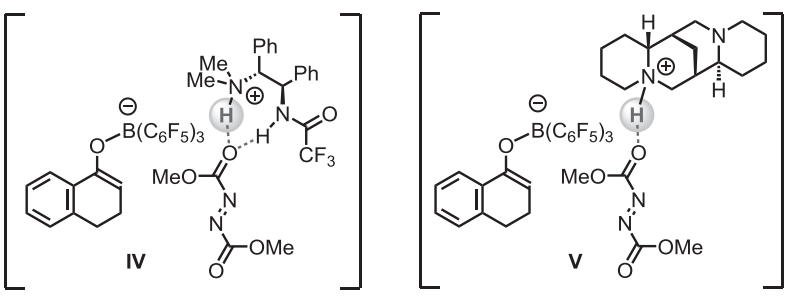

Figure 2. $\alpha$-Amination of carbonyl compounds promoted by frustrated Lewis acid/Brønsted base catalysts. 
Through the use of $\mathrm{B}\left(\mathrm{C}_{6} \mathrm{~F}_{5}\right)_{3}$ and a chiral amine catalyst $(\mathbf{C} 7)$, 2e was produced in $88 \%$ yield and $97: 3$ er. The tertiary amine moiety of $\mathbf{C} 7$ plays the role of a Brønsted base in deprotonation of $\left(\mathrm{F}_{5} \mathrm{C}_{6}\right)_{3} \mathrm{~B}-$ activated 1e. After deprotonation, the amine group would then be transformed into an ammonium ion $(\mathbf{1} \mathbf{e} \rightarrow \mathbf{I V}$, Figure 2c). The amide unit of $\mathbf{C} 7$ and the in situ generated ammonium ion serve as dual hydrogen-bond donors that associate with basic moieties of DMAD; such two-point binding interactions offer conformational restriction necessary for promoting a highly enantioselective $\mathrm{C}-\mathrm{N}$ bond forming process (IV). High enantioselectivity observed using $\mathrm{B}\left(\mathrm{C}_{6} \mathrm{~F}_{5}\right)_{3}$ and $\mathbf{C} 7$ suggests that there is minimal formation of rac-2e through a competing reaction pathway in which DMAD is activated by strongly Lewis acidic $\mathrm{B}\left(\mathrm{C}_{6} \mathrm{~F}_{5}\right)_{3}$.

The significant roles that dual $\mathrm{H}$-bonding interactions play is evidenced by markedly lower er obtained when $\mathbf{C 8}$, prepared by $N$-methylation of $\mathbf{C 7}$, was used as the catalyst (2e, $86 \%$ yield, $80: 20 \mathrm{er}$ ). Furthermore, rac-2e was obtained using $(-)$-sparteine as the base catalyst $(71 \%$ yield). Thus, a single $\mathrm{H}$-bonding interaction between the chiral ammonium ion derived from $\mathbf{C 8}$ or $\mathbf{C} 9$ and DMAD does not sufficiently provide directional catalyst-electrophile binding to produce $\mathbf{2 e}$ with high enantioselectivity (IV vs. V). Thus, the "frustrated" $\left(\mathrm{F}_{5} \mathrm{C}_{6}\right)_{3} \mathrm{~B}$ /amine catalysts were found to facilitate deprotonation of various mono-carbonyl compounds that possess poorly base-sensitive $\alpha-\mathrm{C}-\mathrm{H}$ bonds. Nonetheless, a major limitation of the current catalyst system was the use of a highly pre-activated electrophile such as DMAD, because electrophile activation relies on weakly to moderately acidic $\mathrm{H}$-bond donors; such potent electrophiles can undergo non-stereoselective background reaction when the reaction is performed at room temperature.

\subsection{FLP-catalyzed Enantioselective Conia-ene-type Reaction}

To achieve enantioselective transformations between mono-carbonyl pronucleophiles and less pre-activated electrophiles, we have developed a three-component "frustrated" acid/base catalyst system. ${ }^{17 b}$ The catalyst design principle is that, while $\mathrm{B}\left(\mathrm{C}_{6} \mathrm{~F}_{5}\right)_{3}$ and a $\mathrm{N}$-based Brønsted base deprotonates a carbonyl pronucleophile, a chiral organometallic complex serving as Lewis acid co-catalyst activates a poorly reactive electrophile. As a model transformation, we reported an efficient and enantioselective Conia-ene-type reaction of alkynyl ketone $\mathbf{1 f}$ by implementing the cooperative action of a three-component "frustrated" acid/base catalyst system comprised of a strongly Lewis acidic $\mathrm{B}\left(\mathrm{C}_{6} \mathrm{~F}_{5}\right)_{3}$, a N-based Brønsted base, and a chiral $\mathrm{Zn}-\mathrm{BOX}$ complex (Figure 3). $\mathrm{B}\left(\mathrm{C}_{6} \mathrm{~F}_{5}\right)_{3}$, which is the more oxophilic component of the FLP, coordinates preferentially to the carbonyl moiety whereas the tertiary amine catalyst helps with the formation of the requisite boron enolate $(\mathbf{1} \mathbf{f}-\mathbf{1} \mathbf{i} \rightarrow \mathbf{V I}$, Figure 3 b). Meanwhile, the $\mathbf{Z n}$-based complex plays the role of a $\pi$-Lewis acid, activating the pendant alkyne moiety. Thus, the resulting enolate VII undergoes enantioselective $\mathrm{C}-\mathrm{C}$ bond forming reaction with chiral $\mathrm{Zn}$ BOX-activated alkyne unit of $\mathbf{1 f}-\mathbf{1 i}$ to afford a cyclopentene derivative $\mathbf{2} \mathbf{f}-\mathbf{2 i}$. It was found that Lewis acidic co-catalysts were required for the cycloaddition of $\mathbf{1 f}-\mathbf{1 i}$ to occur because no product was obtained in the absence of either $\mathrm{B}-$ or $\mathrm{Zn}$ based catalyst (Figure 3a). An array of cyclopentene derivatives that possess a quaternary center (2g), (thiophen-2-yl)methanone (2h), or propan-1-one (2i) moieties were obtained (a) Enantioselective Conia-ene-type reactions

Standard reaction conditions:

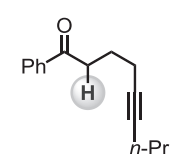

$$
\begin{aligned}
& 5.0 \mathrm{~mol} \% \mathrm{~B}\left(\mathrm{C}_{6} \mathrm{~F}_{5}\right)_{3} \\
& 10 \mathrm{~mol} \% \quad \mathrm{PMP} \\
& \hline \mathrm{CH}_{2} \mathrm{Cl}_{2}, 22^{\circ} \mathrm{C}, 12 \mathrm{~h}
\end{aligned}
$$
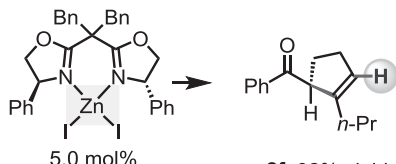

$1 f$ $5.0 \mathrm{~mol} \%$ 2f, $92 \%$ yield 7:3

Control experiment performed in the absence of Zn-based co-catalyst:<smiles>CCCC#CCCC(C)C(=O)c1ccccc1</smiles>

$5.0 \mathrm{~mol} \% \mathrm{~B}\left(\mathrm{C}_{6} \mathrm{~F}_{5}\right)_{3}$

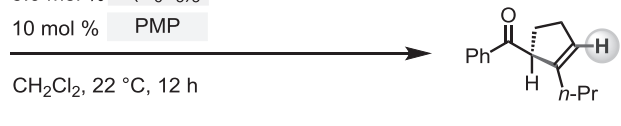

$1 f$

Control experiment performed in the absence of $B\left(C_{6} F_{5}\right)_{3}$ :

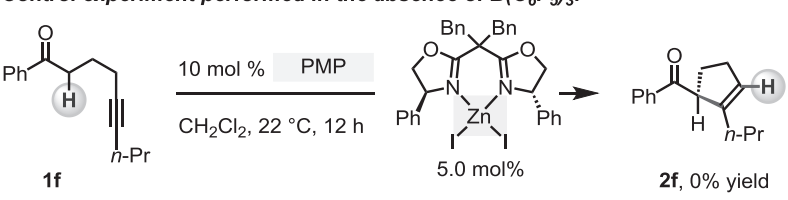

(b) Proposed catalytic cycle:
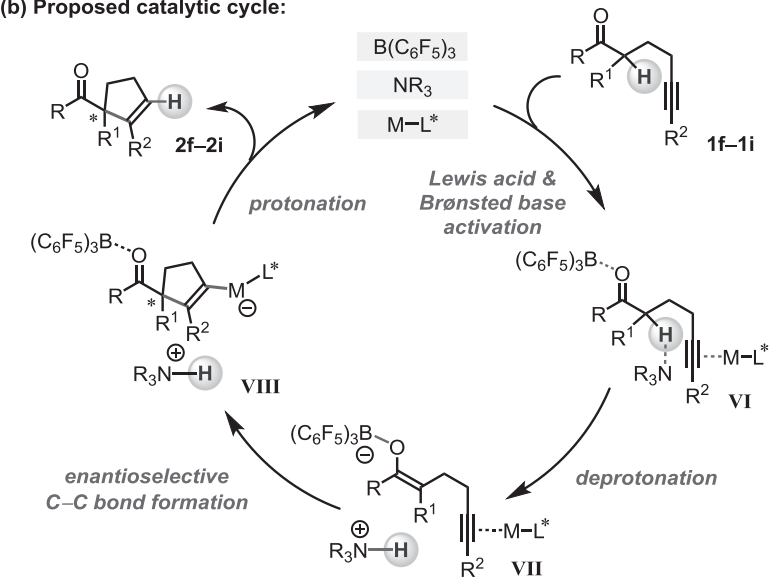

(c) Selected products:

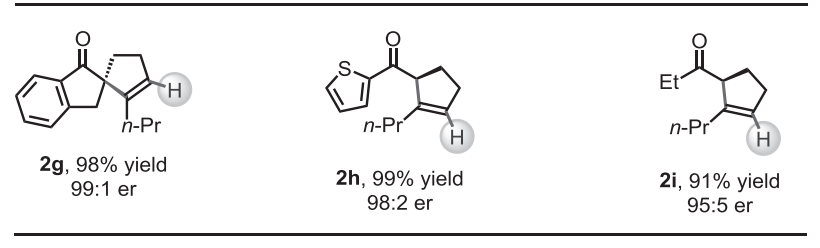

Figure 3. Enantioselective Conia-ene-type reaction promoted by a three-component frustrated Lewis acid/Brønsted base catalysts.

in $95: 5-99: 1$ er.

Therefore, we showed that by tuning the different features of Lewis acids that may possess overlapping functions, it is possible to enable Lewis acid catalysts to serve as an activator of a carbonyl group or an activator of electron-rich alkyne. Accordingly, efficiency and stereoselectivity of $\mathrm{C}-\mathrm{C}$ bond forming reactions between in situ generated enolates and chiral Lewis acid-activated alkynes can be conveniently enhanced without significant loss in er, which might arise due to intervention by an achiral Lewis acid component. The principles outlined in this method, entailing separate and independently operational Lewis acidic co-catalysts and a Brønsted base catalyst, provide a rational framework for the development of processes involving the generation of nucleophiles through deprotonation of pronucleophiles containing a poorly acidic proton, and their ensuing reaction with Lewis acid co-cata- 
lyst-activated electrophiles.

\section{Enantioselective Transformations of $\alpha$ - and $\beta$-Amino $\mathbf{C}-\mathbf{H}$ Bonds by Cooperative Catalysis}

\subsection{Enantioselective $\alpha$-Alkylation of $\boldsymbol{N}$-Alkylamines}

Enantioselective transformations involving $\alpha$-amino $\mathrm{C}-\mathrm{H}$ bonds contained in $N$-alkylamines and promoted by transition metal complexes have received considerable attention, as these processes deliver $\alpha$-substituted amines that are prevalent in pharmaceuticals as well as chiral catalysts that are used in enantioselective synthesis. ${ }^{19-22}$ Particularly attractive are the processes for late-stage $\mathrm{C}-\mathrm{H}$ functionalization of bioactive amines that allow access to an assortment of drug derivatives. ${ }^{23}$ However, the paucity of a versatile and robust class of chiral catalysts limit the applications of such strategies in preparation of complex $\mathrm{N}$-based molecules. Most extant methods employ precious metal-based catalysts (e.g., $\mathrm{Ru}, \mathrm{Rh}, \mathrm{Pd}$-based complexes) ${ }^{19-22}$ that may readily undergo mutual quenching with the Lewis basic amine substrate which may also possess a variety of Lewis acid-sensitive functional groups. Consequently, these methods are limited in the range of applicable nucleophilic and electrophilic components. The development of catalyst systems that are based on sustainable elements and promote enantioselective $\mathrm{C}-\mathrm{H}$ functionalization of polyfunctional amines represent a compelling research objective.

We have developed a method for the enantioselective union of various $N$-alkylamines (3) and $\alpha, \beta$-unsaturated compounds (6) by implementing the cooperative action of two untethered and independently operational Lewis acid catalysts (Figure 4). ${ }^{18 a}$ One key advantage of the approach is that the efficiency and stereoselectivity can be optimized through evaluation of pairs of readily accessible Lewis acids and chiral ligands (vs. bifunctional catalysts needing cumbersome tethering of the catalyst units). ${ }^{3,4}$ A central design principle is that the untethered Lewis acid catalysts must perform their separate tasks without any overlapping of their function, as otherwise, stereoselectivity would suffer (owing to reaction facilitated by the achiral component). ${ }^{2 n}$ Specifically, we illustrated that by properly tuning the structural and electronic features of different Lewis acids and substrates, the ability of $\mathrm{B}\left(\mathrm{C}_{6} \mathrm{~F}_{5}\right)_{3}$ and chiral $(\mathrm{TfO})_{2} \mathrm{Mg} / \mathbf{L} \mathbf{1}$ to serve as a hydride acceptor from $\mathbf{3}$, or an activator of $\mathbf{6}$, can be adjusted. We found out that the racemic $\mathrm{C}-\mathrm{C}$ bond forming reaction of $\mathbf{3 b}$ and $\mathbf{6 a}$ can be catalyzed by $\mathrm{B}\left(\mathrm{C}_{6} \mathrm{~F}_{5}\right)_{3}$ alone (3b and $\mathbf{6 a} \rightarrow \mathbf{I X} \rightarrow \boldsymbol{r a c}-\mathbf{4 a}$, Figure $4 \mathrm{~b}$ ). As a result of this competing racemic process, $\mathbf{4 a}$ can be obtained with only up to $80: 20$ er when the union of $\mathbf{3 b}$ and $\mathbf{6 a}$ is catalyzed by $\mathrm{B}\left(\mathrm{C}_{6} \mathrm{~F}_{5}\right)_{3}$ and $(\mathrm{TfO})_{2} \mathrm{Mg} / \mathrm{L1}$ (4a is formed via either IX $\rightarrow \boldsymbol{r a c}-\mathbf{4 a}$ or $\mathbf{X} \rightarrow \mathbf{4 a})$. To improve enantioselectivity further, we reacted $\mathbf{3 b}$ with a more sterically hindered electrophile $\mathbf{6 b}$ (vs. 6a), which resulted in the formation of $\mathbf{4 b}$ in up to $98: 2 \mathrm{er}$ (Figure 4c). The improved enantioselectivity likely arises from a preference for $\mathbf{L} \mathbf{1} / \mathrm{Mg}$-activated $\mathbf{X I I}$ over $\left(\mathrm{F}_{5} \mathrm{C}_{6}\right)_{3} \mathrm{~B}$-activated $\mathbf{X I}$, the latter of which suffers from severe steric pressure between the gem-dimethyl group of $\mathbf{6} \mathbf{b}$ and $\mathrm{B}\left(\mathrm{C}_{6} \mathrm{~F}_{5}\right)_{3}$. This contention is supported by the fact that $\mathbf{3 b}$ and $\mathbf{6} \mathbf{b}$ do not react in the absence of $(\mathrm{TfO})_{2} \mathrm{Mg} / \mathbf{L} \mathbf{1}$. The principles delineated by (a)<smiles>[R]C([R])[18O]</smiles>

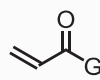

6

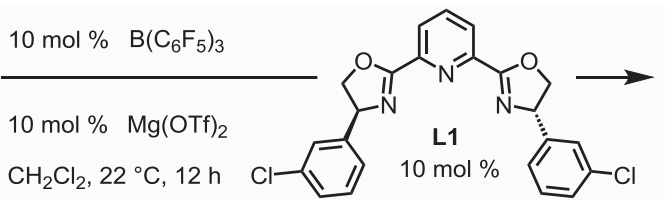<smiles>[R]C([B])C(=O)OCC(N)=O</smiles>

4 , up to $98: 2$ er

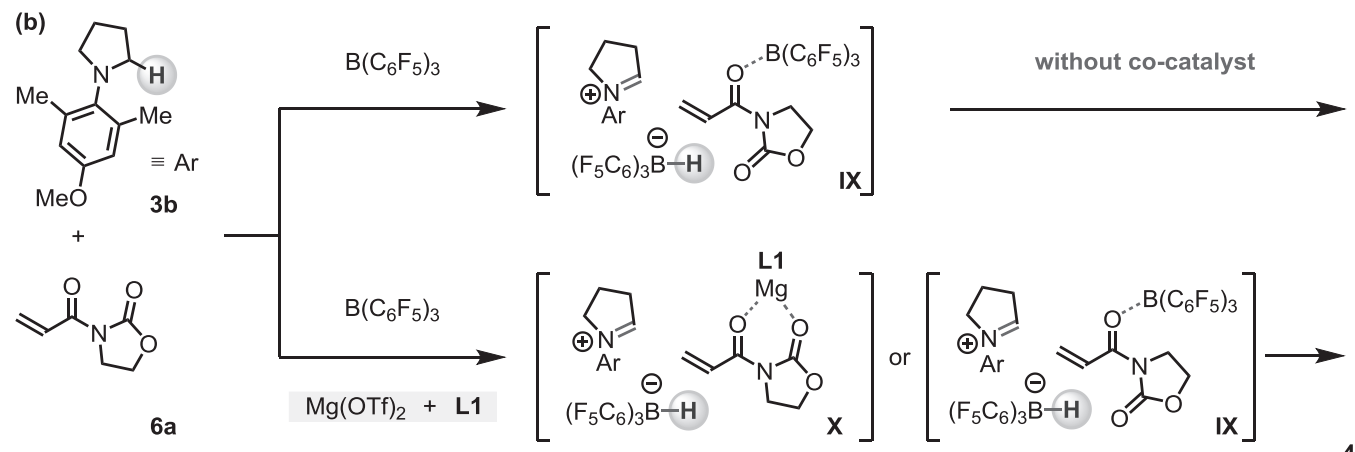

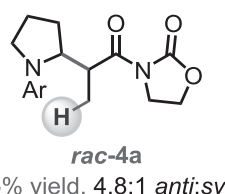

$35 \%$ yield, $4.8: 1$ anti:syn

(c)<smiles>C=CC(=O)N1C(=O)OCC1(C)C</smiles>
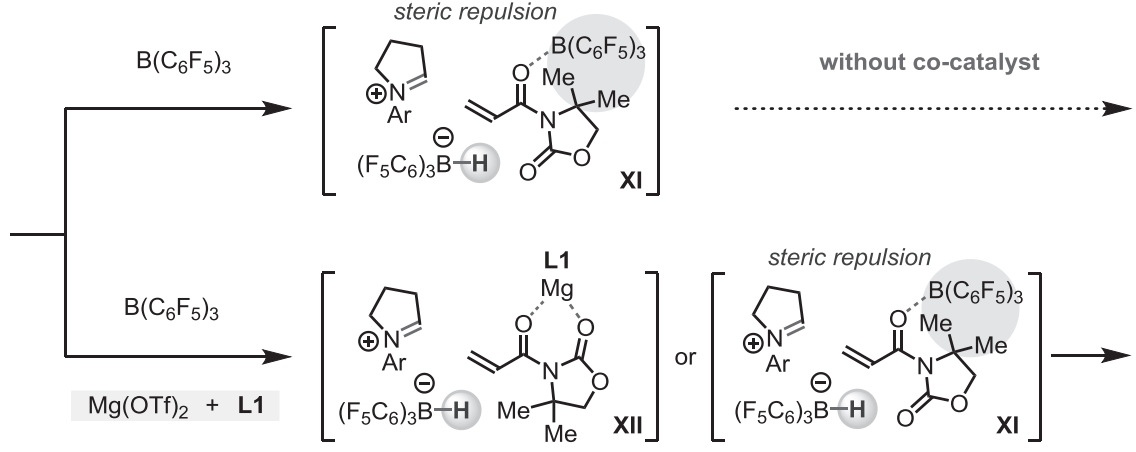

$4 a,>95 \%$ yield, 1.6:1 anti:syn $80: 20$ e.r. (anti), 68:32 e.r. (syn)

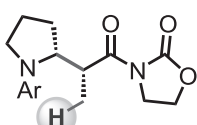

$\mathrm{H}^{\prime}$
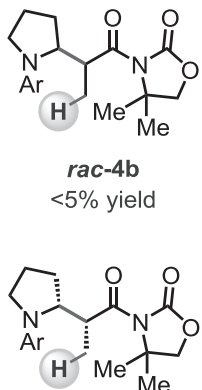

4b, $88 \%$ yield, $4.3: 1$ anti:syn 97:3 e.r. (anti), 98:2 e.r. (syn)

Figure 4. Enantioselective $\alpha$-alkylation of $N$-alkylamines by cooperative Lewis acid/Lewis acid catalysis. 
our work later served as the conceptual framework for the development of new processes that demand separate and independently operational Lewis acidic co-catalysts whose functions overlap and the use of which initially seems to have a negative impact on enantioselectivity.

\subsection{Enantioselective Synthesis of Propargylamines from $\mathrm{N}$-Alkylamines}

In subsequent work, we outlined an approach for activation of $\alpha$-amino $\mathrm{C}-\mathrm{H}$ bonds to generate propargyl amines (Figure 5). ${ }^{18 \mathrm{~b}}$ This catalyst system tolerates a wide variety of Lewis acid-sensitive functional groups, and is therefore applicable to the late-stage transformations of complex (and bioactive) trialkyl amines to propargylamines (e.g., $\mathbf{4 c}-\mathbf{4 f}$; Figure 5a). Furthermore, by using $\mathrm{B}\left(\mathrm{C}_{6} \mathrm{~F}_{5}\right)_{3}$ and a chiral $\mathrm{L}_{\mathrm{n}} \mathrm{Cu}-$ PyBOX (L2) complex, we established that highly enantioselective synthesis of propargylamines can be achieved (e.g., $\mathbf{3 g} \rightarrow \mathbf{4 g}$, Figure 5b). Mechanistic investigations involving the determination of rate orders and kinetic isotope effects were performed to elucidate how the two co-catalysts operate cooperatively. These studies revealed that by using a blend of $\mathrm{B}\left(\mathrm{C}_{6} \mathrm{~F}_{5}\right)_{3}$ and an organocopper complex, it is possible to generate an iminium from an $\mathrm{N}$-alkylamine and a $\mathbf{L 2 - C u}$-alkynyl complex from an alkynylsilane $\mathbf{7}$ (XV, Figure 5c). Specifically, this enantioselective transformation proceeds through the reaction of $\mathrm{B}\left(\mathrm{C}_{6} \mathrm{~F}_{5}\right)_{3}$ and $\mathrm{Ph}_{3} \mathrm{COH}$ to produce an ionic complex (XIII) comprised of trityl cation and $\left[\mathrm{HO}-\mathrm{B}\left(\mathrm{C}_{6} \mathrm{~F}_{5}\right)_{3}\right]^{-}$. The latter species promotes transmetallation between alkynylsilane $\mathbf{7}$ and $\mathbf{L 2}-\mathrm{Cu}-\mathrm{PyBOX}$ complex, producing $\mathbf{X I V}$ and $\mathrm{Me}_{3} \mathrm{Si}-\mathrm{OH}$ as a byproduct. Ensuing $\left(\mathrm{F}_{5} \mathrm{C}_{6}\right)_{3} \mathrm{~B}$-catalyzed hydride abstraction from $\mathbf{3 g}$ furnishes intermediate $\mathbf{X V}$ which then undergoes enantiodetermining $\mathrm{C}$-alkynyl bond forming reaction to afford $\mathbf{4 g}$ and triphenylmethane while regenerating the catalysts with the aid of $\mathrm{Ph}_{3} \mathrm{COH}$.

\subsection{Enantioselective $\beta$-Amino $\mathbf{C}-\mathbf{H}$ Alkylation}

The development of methods for enantioselective synthesis of amines by activation of the difficult-to-access $\beta$-amino $\mathrm{C}^{-}$ $\mathrm{H}$ bond is a major and unresolved challenge. ${ }^{21} \alpha-$ Amino $\mathrm{C}-\mathrm{H}$ activation by a hydrogen atom or hydride transfer is facilitated by the stabilization of the resulting species through electron delocalization from the nitrogen lone pair (e.g., amine $\rightarrow$ iminium ion). ${ }^{19,20}$ Still, such processes do not readily occur at the $\beta$ position of amines. We have discovered that a potent catalyst system comprised of $\mathrm{B}\left(\mathrm{C}_{6} \mathrm{~F}_{5}\right)_{3}$, a chiral $\mathrm{Sc}$-based co-catalyst, and a Brønsted base promotes enantio- and diastereo-selective reactions of $N$-alkylamines (e.g., 3, Figure 6) and $\alpha, \beta$ unsaturated compounds (8) to give $\beta$-alkylated amines $(\mathbf{5 a}-$ 5c). ${ }^{18 c} \mathrm{~A}$ variety of Lewis acid-sensitive functional units are tolerated, and, as a result, the approach is applicable to latestage modification of relatively complex (and bioactive) trialkylamines (e.g., 5b and 5c). Our mechanistic studies have unveiled that the enantioselective $\beta$-amino $\mathrm{C}-\mathrm{H}$ alkylation process occurs through $\left(\mathrm{F}_{5} \mathrm{C}_{6}\right)_{3} \mathrm{~B}$-catalyzed hydride abstraction from $N$-alkylamines 3 to produce an iminium $(\mathbf{3} \rightarrow \mathbf{X V I}$, Figure $6 \mathrm{c}$ ). Then, sequential borohydride reduction of $\left(\mathrm{F}_{5} \mathrm{C}_{6}\right)_{3} \mathrm{~B}$-activated $\alpha, \beta$-unsaturated compound $\mathbf{8 a}$ and protonation of the resulting boron enolate affords an enamine $(\mathbf{X V I} \rightarrow \mathbf{X V I I})$ and reduced 8a. Ensuing enantioselective $\mathrm{C}-\mathrm{C}$ bond forming process between the in situ generated enamine and $\mathbf{L 3}-[\mathrm{Sc}]-$ activated 8a affords a zwitterionic intermediate XVIII. Proton transfer within XVIII produces the desired product $\mathbf{5 b}$ or $\mathbf{5 c}$.

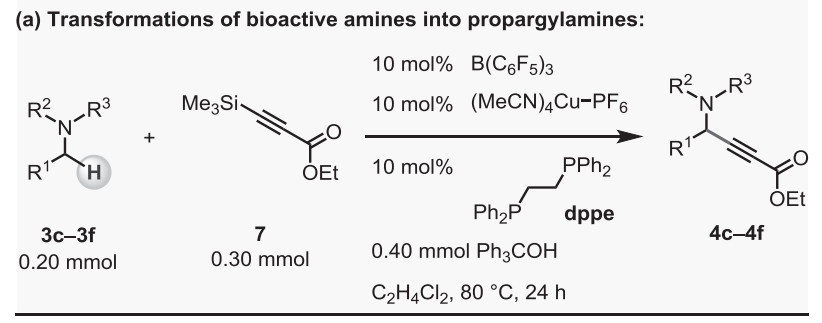

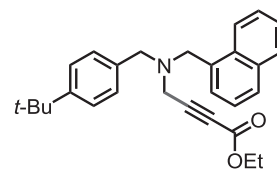

4c, $76 \%$ yield butenafine (antifungal) derivative

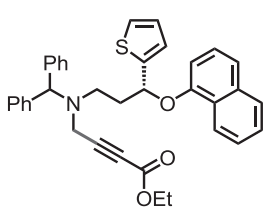

$4 e, 68 \%$ yield duloxetine (antidepressant)
derivative

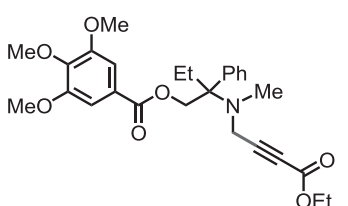

4d, $71 \%$ yield

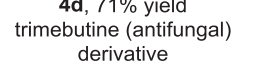
derivative

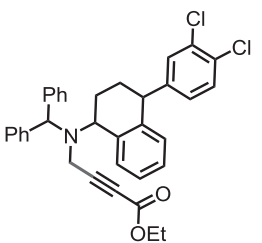

4f, $67 \%$ yield sertraline (antidepressant) derivative

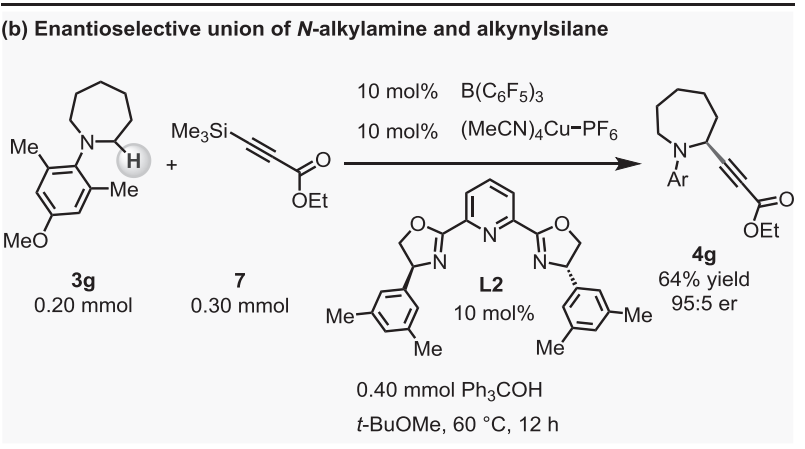

(c) Plausible mechanism

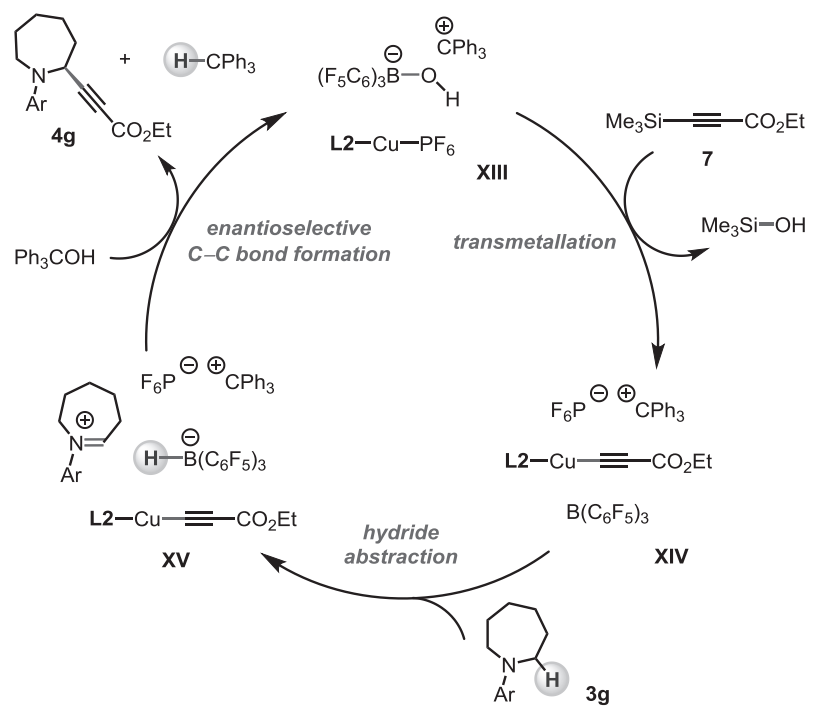

Figure 5. Conversions of $N$-alkylamines into propargylamines by cooperative Lewis acid/Lewis acid catalysis.

\section{Conclusion}

In summary, we have developed cooperative catalyst systems that enable structural modification and diversification of 
(a) Enantioselective $\beta$-Amino $\mathbf{C}-\mathrm{H}$ Alkylation

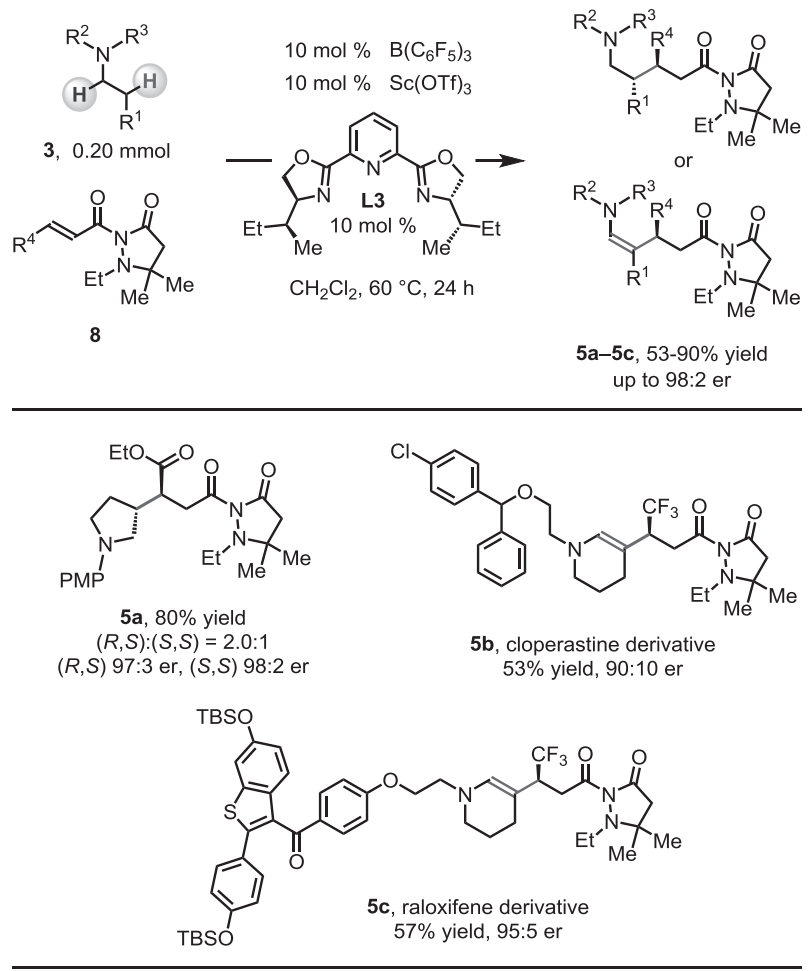

(b) Control experiment performed in the absence of Sc-based co-catalyst

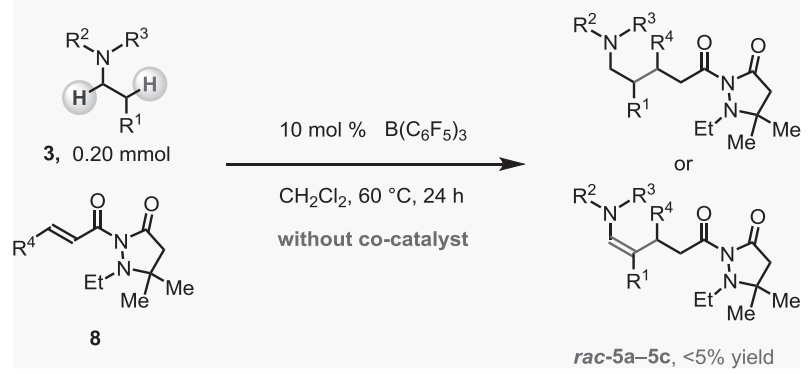

(c) Plausible mechanism

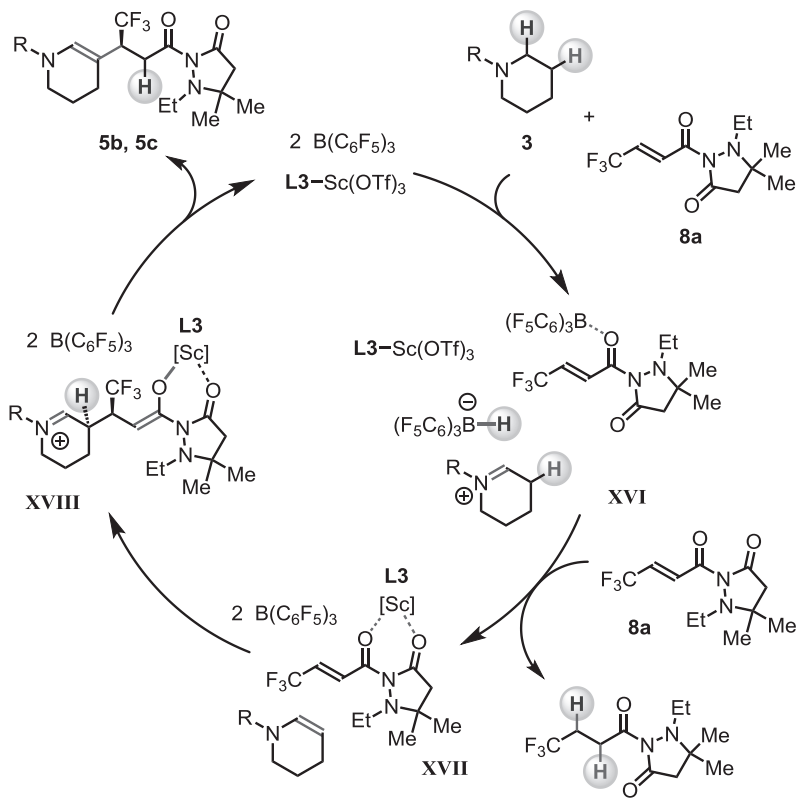

Figure 6. $\quad \beta$-Amino $\mathrm{C}-\mathrm{H}$ alkylation reaction promoted by cooperative Lewis acid/Lewis acid catalysis. an array of polyfunctional molecules at positions that are difficult to access by previously established methods. We have demonstrated that these highly reactive and versatile catalysts can activate $\mathrm{C}-\mathrm{H}$ bonds of poorly base-sensitive carbonyl molecules and relatively complex amines, and subsequently promote transformations of the resulting intermediates. Further catalyst development is likely to lead to additional discoveries regarding generally applicable strategies for natural product synthesis, drug discovery, and determination of the identity of complex molecules.

\section{Acknowledgements}

Financial support was provided by the NIH (GM-128695), Sloan Foundation and Boston College. A. Y. was supported by John and Mary LaMattina, the LaMattina Family Fellowship in Chemical Synthesis.

\section{References}

1) Selected book chapters on enantioselective cooperative catalysis: (a) Shibasaki, M.; Kumagai, N. in Cooperative Catalysis: Designing Efficient Catalysts for Synthesis, Peters, R., Eds.; Wiley-VCH: New York, 2015; Chapter 1. (b) Lu, X.; Deng, L. in Cooperative Catalysis: Designing Efficient Catalysts for Synthesis, Peters, R., Eds.; WileyVCH: New York, 2015; Chapter 5.

2) Selected reviews on enantioselective cooperative catalysis: (a) Ma, J. A.; Cahard, D. Angew. Chem. Int. Ed. 2004, 43, 4566. (b) Kanai, M.; Kato, N.; Ichikawa, E.; Shibasaki, M. Synlett 2005, 1491. (c) Yamamoto, H.; Futatsugi, K. Angew. Chem. Int. Ed. 2005, 44, 1924. (d) Akiyama, T. Chem. Rev. 2007, 107, 5744. (e) Terada, M. Chem. Commun. 2008, 4097. (f) Paull, D. H.; Abraham, C. J.; Scerba, M. T.; Alden-Danforth, E.; Lectka, T. Acc. Chem. Res. 2008, 41, 655. (g) Kobayashi, S.; Mori, Y.; Fossey, J. S.; Salter, M. M. Chem. Rev. 2011 111, 2626. (h) Fulton, J. R.; Glover, J. E.; Kamara, L.; Rowlands, G. J. Chem. Commun. 2011, 47, 433. (i) Allen, A. E.; MacMillan, D. W. C. Chem. Sci. 2012, 3, 633. (j) Park, J.; Hong, S. Chem. Soc. Rev. 2012, 41, 6931. (k) Matsunaga, S.; Shibasaki, M.; Chem. Commun. 2014, 50, 1044. (1) Trost, B. M.; Bartlett, M. J. Acc. Chem. Res. 2015, 48, 688 (m) Wang, M. H.; Scheidt, K. A. Angew. Chem. Int. Ed. 2016, 55, 14912. (n) Romiti, F.; del Pozo, J; Paioti, P. H. S.; Gonsales, S. A.; Li, X.; Hartrampf, F. W. W.; Hoveyda, A. H. J. Am. Chem. Soc. 2019 141, 17952.

3) Selected reviews on enantioselective $\alpha$-functionalization of carbonyl compounds through in situ generation of enolates: (a) Evans, D. A. Aldrichimica Acta 1982, 15, 23. (b) Evans, D. A.; Shaw, J. T. Actual. Chim. 2003, 35. (c) Modern Aldol Reactions, Vol. 1, 2; R. Mahrwald Ed.; Wiley-VCH, Weinheim, 2004. (d) Palomo, C.; Oiarbide, M.; García, J. M. Chem. Soc. Rev. 2004, 33, 65. (e) Mukaiyama, T. in Organic Reactions; John Wiley \& Sons, Inc. 2004; Chapter 3. (f) List, B. Acc. Chem. Res. 2004, 37, 548. (g) Notz, W.; Tanaka, F.; Barbas III, C. F. Acc. Chem. Res. 2004, 37, 580. (h) Mukherjee, S.; Yang, J. W. Hoffmann, S.; List, B. Chem. Rev. 2007, 107, 5471. (i) Hashimoto, T.; Maruoka, K. Chem. Rev. 2007, 107, 5656. (j) Ooi, T.; Maruoka, K. Angew. Chem. Int. Ed. 2007, 46, 4222. (k) Adair, G.; Mukherjee, S.; List, B. Aldrichimica Acta 2008, 41, 31. (1) Zhang, Z.; Schreiner, P. R. Chem. Soc. Rev. 2009, 38, 1187. (m) Trost, B. M.; Brindle, C. S. Chem. Soc. Rev. 2010, 39, 1600. (n) Phipps, R. J.; Hamilton, G. L.; Toste, F D. Nat. Chem. 2012, 4, 603. (o) Benohoud, M., Hayashi, Y. in "Asymmetric Organocatalysis 1: Lewis Base and Acid Catalysts", List, B., Eds.; George Thieme Verlag KG: Stuttgart, 2012, pp 73-134. (p) Brak, K.; Jacobsen, E. N. Angew. Chem. Int. Ed. 2013, 52, 534. (q) Matsuo, J.; Murakami, M. Angew. Chem. Int. Ed. 2013, 52, 9109. (r) Hayashi, Y. J. Synth. Org. Chem., Jpn. 2014, 72, 1228.

4) For reviews of hydrogen bonding catalysis, see: (a) Schreiner, P. R. Chem. Soc. Rev. 2003, 32, 289. (b) Takemoto, Y. Org. Biomol. Chem. 2005, 3, 4299. (c) Connon, S. J. Chem. Eur. J. 2006, 12, 5418. (d) Taylor, M. S.; Jacobsen, E. N. Angew. Chem. Int. Ed. 2006, 45, 1520. (e) Doyle, A. G.; Jacobsen, E. N. Chem. Rev. 2007, 107, 5713. (f) Knowles, R. R.; Jacobsen, E. N. Proc. Natl. Acad. Sci. U.S.A. 2010, 107, 20678.

5) Representative examples of enantioselective catalytic $\alpha$-functionalization of carbonyl compounds through in situ generation of enolates: (a) List, B.; Lerner, R. A.; Barbas, C. F. J. Am. Chem. Soc. 2000, 122, 
2395. (b) Chen, Y.; Tian, S.-K.; Deng, L. J. Am. Chem. Soc. 2000, 122, 9542. (c) Trost, B. M.; Ito, H. J. Am. Chem. Soc. 2000, 122, 12003. (d) Okino, T.; Hoashi, Y.; Takemoto, Y. J. Am. Chem. Soc. 2003, 125, 12672. (e) Uraguchi, D.; Terada, M. J. Am. Chem. Soc. 2004, 126, 5356. (f) Song, J.; Wang, Y.; Deng, L. J. Am. Chem. Soc. 2006, 128, 6048. (g) Yamaoka, Y.; Miyabe, H.; Yasui, Y.; Takemoto, Y. Synthesis 2007, 2571. (h) Yazaki, R.; Kumagai, N.; Shibasaki, M. J. Am. Chem. Soc. 2009, 131, 3195. (i) Yin, L.; Brewitz, L.; Kumagai, N.; Shibasaki, M. J. Am. Chem. Soc. 2014, 136, 17958. (j) Yang, X.; Toste, F. D. J. Am. Chem. Soc. 2015, 137, 3205. (k) Hayashi, Y.; Umekubo, N. Angew. Chem. Int. Ed. 2018, 57, 1958.

6) $\mathrm{Xu}, \mathrm{H} . ;$ Zuend, S. J.; Woll, M. G.; Tao, Y.; Jacobsen, E. N. Science 2010, 327, 986.

7) Manville, N.; Alite, H.; Haeffner, F.; Hoveyda, A. H.; Snapper, M. L. Nat. Chem. 2013, 5, 768

8) Han, Z.-Y.; Xiao, H.; Chen, X.-H.; Gong, L.-Z. J. Am. Chem. Soc. 2009, 131, 9182 .

9) Selected reviews on FLP chemistry: (a) Stephan, D. W.; Erker, G. Angew. Chem. Int. Ed. 2010, 49, 46. (b) Stephan, D. W., Erker, G., Eds. Frustrated Lewis Pairs I: Uncovering and Understanding; Topics in Current Chemistry Series Vol. 332; Springer: Berlin, 2013. (c) Erker, G., Stephan, D. W., Eds. Frustrated Lewis Pairs II: Expanding the Scope; Topics in Current Chemistry Series Vol. 334; Springer: Berlin, 2013. (d) Stephan, D. W.; Erker, G. Angew. Chem. Int. Ed. 2015, 54, 6400. (e) Stephan, D. W. J. Am. Chem. Soc. 2015, 137, 10018. (f) Stephan, D. W. Science 2016, 354, No. aaf7229. (g) Meng, W.; Feng, X.; Du, H. Acc. Chem. Res. 2018, 51, 191. (h) Stephan, D. W. Chem. 2020, 6, 1520. (i) Ma, Y; Luo, S.-J.; Hou, Z. Chem. Soc. Rev. 2021, 50, 1945. (j) Basak, S.; Winfret, L.; Kustiana, B. A.; Melen, R. L.; Morrill, L. C.; Pulis, A. P. Chem. Soc. Rev. 2021, 50, 3720.

10) Selected examples involving carboxylic acids, esters, amides and thioesters serving as pronucleophiles: (a) Alonso, D. A.; Kitagaki, S.; Utsumi, N.; Barbas III, C. F. Angew. Chem. Int. Ed. 2008, 47, 4588. (b) Yamashita, Y.; Suzuki, H.; Kobayashi, S. Org. Biomol. Chem. 2012, 10, 5750. (c) Bahlinger, A.; Fritz, S. P.; Wennemers, H. Angew. Chem. Int. Ed. 2014, 53, 8779. (d) Yin, L.; Brewitz, L.; Kumagai, N.; Shibasaki, M. J. Am. Chem. Soc. 2014, 136, 17958. (e) Suzuki, H.; Sato, I.; Yamashita, Y.; Kobayashi, S. J. Am. Chem. Soc. 2015, 137, 4336. (f) Sun, Z ; Weidner, K.; Kumagai, N.; Shibasaki, M. Chem. Eur. J. 2015, 21, 17574. (g) Morita, Y.; Yamamoto, T.; Nagai, H.; Shimizu, Y.; Kanai, M. J. Am. Chem. Soc. 2015, 137, 7075. (h) Brewitz, L.; Arteaga, F. A.; Yin, L.; Alagiri, K.; Kumagai, N.; Shibasaki, M. J. Am. Chem. Soc. 2015, 137, 15929. (i) Arteaga, F. A.; Liu, Z.; Brewitz, L.; Chen, J.; Sun, B.; Kumagai, N.; Shibasaki, M. Org. Lett. 2016, 18 , 2391. (j) Sun, B.; Balaji, P. V.; Kumagai, N.; Shibasaki, M. J. Am. Chem. Soc. 2017, 139, 8295. (k) Saito, A.; Kumagai, N.; Shibasaki, M. Angew. Chem. Int. Ed. 2017, 56, 5551. (1) Sun, B.; Pluta, R.; Kumagai, N.; Shibasaki, M. Org. Lett. 2018, 20, 526. (m) Li, Z.; Noda, H.; Kumagai, N.; Shibasaki, M. Tetrahedron 2018, 74, 3301. (n) Yamashita, Y; Kobayashi, S. Chem. Eur. J. 2018, 24, 10. (o) Kumagai, N.; Shibasaki, M. Synthesis 2019, 51, 185. (p) Yu, J.-S.; Noda, H.; Kumagai, N.; Shibasaki, M. Synlett 2019, 30, 488. (q) He, Z.-T.; Jiang, X.; Hartwig, J. F. J. Am. Chem. Soc. 2019, 141, 13066. (r) Yamashita, Y.; Noguchi, A.; Fushimi, S.; Hatanaka, M.; Kobayashi, S. J. Am. Chem. Soc. 2021, 143, 5598.

11) Selected examples on $\mathrm{H}_{2}$ splitting and catalytic reduction reactions promoted by FLPs: (a) Welch, G. C.; Juan, R. R. S.; Masuda, J. D.; Stephan, D. W. Science 2006, 314, 1124. (b) Welch, G. C.; Stephan, D. W. J. Am. Chem. Soc. 2007, 129, 1880. (c) Spies, P.; Erker, G.; Kehr, G.; Bergander, K.; Frchlich, R.; Grimme, S.; Stephan, D. W. Chem. Commun. 2007, 5072. (d) McCahill, J. S. J.; Welch, G. C.; Stephan, D. W. Angew. Chem. Int. Ed. 2007, 46, 4968. (e) Chase, P. A.; Stephan, D. W. Angew. Chem. Int. Ed. 2008, 47, 7433. (f) Spies, P.; Schwendemann, S.; Lange, S.; Kehr, G.; Fröhlich, R.; Erker, G. Angew. Chem. Int. Ed. 2008, 47, 7543. (g) Wang, H. D.; Fröhlich, R.; Kehr, G.; Erker, G. Chem. Commun. 2008, 5966. (h) Chen, D.; Wang, Y.; Klankermayer, J. Angew. Chem. Int. Ed. 2010, 49, 9475. (i) Stephan, D. W.; Greenberg, S.; Graham, T. W.; Chase, P.; Hastie, J. J.; Geier, S. J.; Farrell, J. M.; Brown, C. C.; Heiden, Z. M; Welch, G. C.; Ullrich, M. Inorg. Chem. 2011, 50, 12338. (j) Sumerin, V.; Chernichenko, K.; Nieger, M.; Leskelä, M.; Rieger, B.; Repo, T. Adv. Synth. Catal. 2011, 353, 2093. (k) Ghattas, G.; Chen, D.; Pan, F.; Klankermayer, J. Dalton Trans. 2012, 41, 9026. (1) Liu, Y.; Du, H. J. Am. Chem. Soc. 2013, 135, 6810. (m) Wei, S.; Du, H. J. Am. Chem. Soc. 2014, 136, 12261. (n) Mahdi, T.; Stephan, D. W. J. Am. Chem. Soc. 2014, 136, 15809. (o) Lindqvist, M.; Borre, K.; Axenov, K.; Kótai, B.; Nieger, M.; Leskelä, M.; Pápai, I.; Repo, T. J. Am. Chem. Soc. 2015, 137, 4038. (p) Ye, K.-Y.; Wang,
X.; Daniliuc, C. G.; Kehr, G.; Erker, G. Eur. J. Inorg. Chem. 2017, 2017, 368. (q) Tu, X.-S.; Zeng, N.-N.; Li, R.-Y.; Zhao, Y.-Q.; Xie, D.-Z.; Peng, Q.; Wang, X.-C. Angew. Chem. Int. Ed. 2018, 57, 15096.

12) Selected examples on arylboron-mediated activation of small molecules: (a) Ishihara, K.; Yamamoto, H. Eur. J. Org. Chem. 1999, 527. (b) Mömming, C. M.; Otten, E.; Kehr, G.; Fröhlich, R.; Grimme, S.; Stephan, D. W.; Erker, G. Angew. Chem. Int. Ed. 2009, 48, 6643. (c) Ashley, A. E.; Thompson, A. L.; O’Hare, D. Angew. Chem. Int. Ed. 2009, 48, 9839. (d) Dureen, M. A.; Stephan, D. W. J. Am. Chem. Soc. 2009, 131, 8396. (e) Otten, E.; Neu, R. C.; Stephan, D. W. J. Am Chem. Soc. 2009, 131, 9918. (f) Voss, T.; Chen, C.; Kehr, G.; Nauha, E.; Erker, G.; Stephan, D. W. Chem. Eur. J. 2010, 16, 3005. (g) Ashley, A. E.; O'Hare, D. Top. Curr. Chem. 2012, 334, 191. (h) Voss, T.; Mahdi, T.; Otten, E.; Fröhlich, R.; Kehr, G.; Stephan, D. W.; Erker, G Organometallics 2012, 31, 2367. (i) Courtemanche, M. A.; Legare, M. A.; Maron, L.; Fontaine, F. G. J. Am. Chem. Soc. 2013, 135, 9326. (j) Sajid, M.; Elmer, L. M.; Rosorius, C.; Daniliuc, C. G.; Grimme, S. Kehr, G.; Erker, G. Angew. Chem. Int. Ed. 2013, 52, 2243. (k) Sajid, M.; Klose, A.; Birkmann, B.; Liang, L. Y.; Schirmer, B.; Wiegand, T.; Eckert, H.; Lough, A. J.; Frohlich, R.; Daniliuc, C. G.; Grimme, S.; Stephan, D. W.; Kehr, G.; Erker, G. Chem. Sci. 2013, 4, 213. (1) Mahdi, T.; Stephan, D. W. Angew. Chem. Int. Ed. 2013, 52, 12418. (m) Voicu, D.; Abolhasani, M.; Choueiri, R.; Lestari, G.; Seiler, C.; Menard, G.; Greener, J.; Guenther, A.; Stephan, D. W.; Kumacheva, E. J. Am. Chem. Soc. 2014, 136, 3875. (n) Dornan, P. K.; Longobardi, L. E.; Stephan, D. W. Synlett 2014, 25, 1521.

13) Selected examples on $\left(\mathrm{F}_{5} \mathrm{C}_{6}\right){ }_{3} \mathrm{~B}$-mediated hydride transfer: (a) Millot, N.; Santini, C. C.; Fenet, B.; Basset, J. M. Eur. J. Inorg. Chem. 2002, 2002, 3328. (b) Focante, F.; Mercandelli, P.; Sironi, A.; Resconi, L. Coord. Chem. Rev. 2006, 250, 170. (c) Dureen, M. A.; Brown, C. C.; Stephan, D. W. Organometallics 2010, 29, 6422. (d) Schwendemann, S.; Fröhlich, R.; Kehr, G.; Erker, G. Chem. Sci. 2011, 2, 1842. (d) Chen, G.-Q.; Kehr, G.; Daniliuc, C. G.; Bursch, M.; Grimme, S. Erker, G. Chem. Eur. J. 2017, 23, 4723.

14) Selected examples on $\left(\mathrm{F}_{5} \mathrm{C}_{6}\right)_{3} \mathrm{~B}$-catalyzed $\alpha$-amino $\mathrm{C}-\mathrm{H}$ functionalization: (a) Farrell, J. M.; Heiden, Z. M.; Stephan, D. W. Organometallics 2011, 30, 4497. (b) Maier, A. F. G.; Tussing, S.; Zhu, H.; Wicker, G.; Tzvetkova, P.; Flörke, U.; Daniliuc, C. G.; Grimme, S.; Paradies, J. Chem. Eur. J. 2018, 24, 16287. (c) Tian, J.-J.; Zeng, N.-N.; Liu, N.; Tu, X.-S.; Wang, X.-C. ACS Catal. 2019, 9, 295. (d) Chan, J. Z.; Chang, Y.; Wasa, M. Org. Lett. 2019, 21, 984. (e) Zhang, J.; Chang, S. J. Am. Chem. Soc. 2020, 142, 12585. (f) Basak, S.; Alvarez-Montoya, A.; Winfrey, L.; Melen, R. L.; Morrill, L. C.; Pulis, A. P. ACS Catal. 2020, 10, 4835. (g) Zhang, M.; Wang, X.-C. Angew. Chem. Int. Ed. 2021, 60, 17185 .

15) Selected examples on $\left(\mathrm{F}_{5} \mathrm{C}_{6}\right)_{3} \mathrm{~B}$-catalyzed $\beta$-amino $\mathrm{C}-\mathrm{H}$ functionalization: (a) Zhang, J.; Park, S.; Chang, S. J. Am. Chem. Soc. 2018, 140 13209. (b) Chang, Y.; Yesilcimen, A.; Cao, M.; Zhang, Y.; Zhang, B.; Chan, J. Z.; Wasa, M. J. Am. Chem. Soc. 2019, 141, 14570. (c) Li, R.; Chen, Y.; Jiang, K.; Wang, F.; Lu, C.; Nie, J.; Chen, Z.; Yang, G.; Chen, Y.-C.; Zhao, Y.; Ma, C. Chem. Commun. 2019, 55, 1217. (d) Chen, Y.; Wan, H. L.; Huang, Y.; Liu, S.; Wang, F.; Lu, C.; Nie, J.; Chen, Z.; Yang, G.; Ma, C. Org. Lett. 2020, 22, 7797.

16) (a) Maier, A. F. G.; Tussing, S.; Schneider, T.; Floörke, U.; Qu, Z.-W.; Grimme, S.; Paradies, J. Angew. Chem. Int. Ed. 2016, 55, 12219. (b) Kojima, M.; Kanai, M. Angew. Chem. Int. Ed. 2016, 55, 12412.

17) (a) Shang, M.; Wang, X.; Koo, S. M.; Youn, J.; Chan, J. Z.; Yao, W.; Hastings, B. T.; Wasa, M. J. Am. Chem. Soc. 2017, 139, 95. (b) Cao, M.; Yesilcimen, A.; Wasa, M. J. Am. Chem. Soc. 2019, 141, 4199.

18) $\left(\mathrm{F}_{5} \mathrm{C}_{6}\right)_{3} \mathrm{~B}$-catalyzed enantioselective $\alpha-$ and $\beta$-amino $\mathrm{C}-\mathrm{H}$ functionalization of amines: (a) Shang, M.; Chan, J. Z.; Cao, M.; Chang, Y.; Wang, Q.; Cook, B.; Torker, S.; Wasa, M. J. Am. Chem. Soc. 2018, 140, 10593. (b) Chan, J. Z.; Yesilcimen, A.; Cao, M.; Zhang, Y.; Zhang, B.; Wasa, M.; J. Am. Chem. Soc. 2020, 142, 16493. (c) Chang, Y.; Cao, M.; Chan, J. Z.; Zhao, C.; Wang, Y.; Yang, R.; Wasa, M. J. Am. Chem. Soc. 2021, 143, 2441.

19) Selected reviews on amino $\mathrm{C}-\mathrm{H}$ bond functionalization: (a) Dick, A. R.; Sanford, M. S. Tetrahedron 2006, 62, 2439. (b) Campos, K. R. Chem. Soc. Rev. 2007, 36, 1069. (c) Davies, H. M.; Manning, J. R. Nature 2008, 451, 417. (d) Baudoin, O. Chem. Soc. Rev. 2011, 40 4902. (e) Mitchell, E. A.; Peschiulli, A.; Lefevre, N.; Meerpoel, L.; Maes, B. U. W. Chem. Eur. J. 2012, 18, 10092. (f) Girard, S. A.; Knauber, T.; Li, C.-J. Angew. Chem. Int. Ed. 2014, 53, 74. (g) Haibach, M. C.; Seidel, D. Angew. Chem. Int. Ed. 2014, 53, 5010. (h) Daugulis, O.; Roane, J.; Tran, L. D. Acc. Chem. Res. 2015, 48, 1053. (i) He, J.; Wasa, M.; Chan, K. S. L.; Shao, Q.; Yu, J.-Q. Chem. Rev. 2017 117, 8754. (j) Chu, J. C. K.; Rovis, T. Angew. Chem. Int. Ed. 2018, 57, 
62. (k) Davies, H. M.; Liao, K. Nat. Rev. Chem. 2019, 3, 347. (1) He, C.; Whitehurst, W. G.; Gaunt, M. J. Chem 2019, 5, 1031. (m) Trowbridge, A.; Walton, S. M.; Gaunt, M. J. Chem. Rev. 2020, 120, 2613

20) Selected examples on $\alpha$-amino $\mathrm{C}-\mathrm{H}$ bond functionalization: (a) Davies, H. M.; Venkataramani, C.; Hansen, T.; Hopper, D. W. J. Am. Chem. Soc. 2003, 125, 6462. (b) Li, Z.; Li, C.-J. J. Am. Chem. Soc. 2004, 126, 11810. (c) Li, Z.; Li, C.-J. Org. Lett. 2004, 6, 4997. (d) Campos, K. R.; Klapars, A.; Waldman, J. H.; Dormer, P. G.; Chen, C. Y. J. Am. Chem. Soc. 2006, 128, 3538. (e) DiRocco, D. A.; Rovis, T. J. Am. Chem. Soc. 2012, 134, 8094. (f) Cordier, C. J.; Lundgren, R. J.; Fu, G. C. J. Am. Chem. Soc. 2013, 135, 10946. (g) Jain, P.; Verma, P.; Xia, G.; Yu, J. Q. Nat. Chem. 2017, 9, 140. (h) Chen, W.; Ma, L.; Paul, A.; Seidel, D. Nat. Chem. 2018, 10, 165. (i) Paul, A.; Seidel, D. J. Am. Chem. Soc. 2019, 141, 8778. (j) Lin, W.; Zhang, K.-F.; Baudoin, O. Nat. Catal. 2019, 2, 882. (k) Neubert, L.; Michalik, D.; Bahn, S.; Imm, S.; Neumann, H.; Atzrodt, J.; Derdau, V.; Holla, W.; Beller, M. J. Am. Chem. Soc. 2012, 134, 12239. (1) Liu, W.; Babl, T.; Röther, A.; Reiser, O.; Davies, H. M. Chem. Eur. J. 2020, 26, 4236.

21) Selected examples on $\beta$-amino $\mathrm{C}-\mathrm{H}$ bond functionalization: (a) Millet, A.; Dailler, D.; Larini, P.; Baudoin, O. Angew. Chem. Int. Ed. 2014, 53, 2678. (b) McNally, A.; Haffemayer, B.; Collins, B. S. L.; Gaunt, M. J. Nature 2014, 510, 129. (c) He, J.; Li, S.; Deng, Y.; Fu, H.; Laforteza, B. N.; Spangler, J. E.; Homs, A.; Yu, J.-Q. Science 2014, 343, 1216. (d) Smalley, A. P.; Gaunt, M. J. J. Am. Chem. Soc. 2015, 137, 10632. (e) Willcox, D.; Chappell, B. G. N.; Hogg, K. F.; Calleja, J.; Smalley, A. P.; Gaunt, M. J. Science 2016, 354, 851. (f) Huang, Z.; Wang, C.; Dong, G. Angew. Chem. Int. Ed. 2016, 55, 5299. (g) Cabrera-Pardo, J. R.; Trowbridge, A.; Nappi, M.; Ozaki, K.; Gaunt, M. J. Angew. Chem. Int. Ed. 2017, 56, 11958. (h) Hogg, K. F.; Trowbridge, A.; Alvarez-Pérez, A.; Gaunt, M. J. Chem. Sci. 2017, 8, 8198. (i) He, Y.; Wang, F.; Zhang, X.; Fan, X Chem. Commun. 2017, 53, 4002. (j) Smalley, A. P.; Cuthbertson, J. D.; Gaunt, M. J. J. Am. Chem. Soc. 2017, 139, 1412. (k) Nappi, M.; He, C.; Whitehurst, W. G.; Chappell, B. G. N.; Gaunt, M. J. Angew. Chem. Int. Ed. 2018, 57, 3178. (1) Su, B.; Lee, T.; Hartwig, J. F. J. Am. Chem. Soc. 2018, 140, 18032.

22) Selected examples on remote amino $\mathrm{C}-\mathrm{H}$ bond functionalization: (a) Xu, Y.; Young, M. C.; Wang, C.; Magness, D. M.; Dong, G. Angew. Chem. Int. Ed. 2016, 55, 9084. (b) Topczewski, J. J.; Cabrera, P. J.; Saper, N. I.; Sanford, M. S. Nature 2016, 531, 220. (c) Zhuang, Z.; Yu, J. Q. J. Am. Chem. Soc. 2020, 142, 12015. (d) Rodrigalvarez, J.; Nappi, M.; Azuma, H.; Floden, N. J.; Burns, M. E.; Gaunt, M. J. Nat. Chem. 2020, $12,76$.

23) (a) Nugent, T. C., Ed. Chiral Amine Synthesis: Methods, Developments and Applications; Wiley-VCH Verlag $\mathrm{GmbH} \& \mathrm{Co}$. KGaA: Weinheim, 2010; pp 15-457. (b) McGrath, N. A.; Brichacek, M.;
Njardarson, J. T. J. Chem. Educ. 2010, 87, 1348. (c) Vardanyan, R. Piperidine-Based Drug Discovery; Elsevier, 2017; p147. (d) Campos, K. R.; Coleman, P. J.; Alvarez, J. C.; Dreher, S. D.; Garbaccio, R. M.; Terrett, N. K.; Tillyer, R. D.; Truppo, M. D.; Parmee, E. R. Science 2019, 363, No. eaat0805. (e) Börgel, J.; Ritter, T. Chem 2020, 6, 1877.

\section{PROFILE}

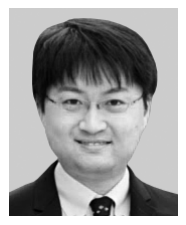

Masayuki Wasa has been an Assistant Professor of Chemistry at Boston College since 2015. He received his $\mathrm{Ph} . \mathrm{D}$. at the Scripps Research Institute in La Jolla, California in 2013, where he investigated organopalladium-catalyzed alkyl $\mathrm{C}-\mathrm{H}$ activation reactions in the laboratory of Professor Jin-Quan Yu. Subsequently, he joined the group of Professor Eric Jacobsen as a Japan Society for the Promotion of Science (JSPS) postdoctoral fellow where he developed enantioselective methods using hydrogen bond donor catalysts between 2013 and 2015. His independent research program in Boston College is focused on the innovations of "frustrated" Lewis pair catalysts that can be applied for late stage transformations of various bioactive organic molecules.

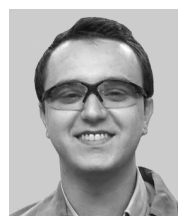

Ahmet Yesilcimen obtained his B.Sc. degree in Chemistry in 2017 from University of Michigan, Ann Arbor. He then moved to Boston, M.A. to initiate his Ph.D. studies at Boston College Chemistry Department. He has been working under the supervision of Prof. Masayuki Wasa since 2018. His graduate research focuses on the regio- and stereoselective late-stage $\mathrm{C}-\mathrm{H}$ functionalization of various bioactive molecules. 